\title{
ОСОБЛИВОСТІ ФОРМУВАННЯ ТА РОЗПОДІЛ ПРИБУТКУ ПІДПРИЕМСТВА
}

\section{FORMING FEATURES AND DISTRIBUTION OF PROFIT OF ENTERPRISE}

\author{
Колісник Олена Пилипівна \\ кандидат економічних наук, доцент, \\ Університет державної фріскальної служби України \\ ORCID: https://orcid.org/0000-0003-1755-5638 \\ Томша Ауріка Олегівна \\ здобувач першого (бакалаврського) рівня вищої освіти, \\ Університет державної фріскальної служби України \\ ORCID: https://orcid.org/0000-0001-8236-9562 \\ Kolisnyk Olena, Tomsha Aurika \\ University of the State Fiscal Service of Ukraine
}

\begin{abstract}
Стаття присвячена дослідженню теоретичних основ формування прибутку підприємства та визначення основних методів управління ним. Визначено основні фрактори впливу на формування прибутку підприємства. Досліджено особливості фрормування прибутку та його розподіл для успішного ведення фрінансово-господарської діяльності суб'єкта господарювання. Оскільки основною метою розподілу прибутку підприємства, який залишається у його розпорядженні, є оптимізація пропорції між частиною чистого прибутку, що споживається, та частиною, що залишається у кругообігу коштів підприємства. А процес фрормування прибутку є цілою сукупністю форм та методів, які дозволяють підприємству оптимізувати та збільшити свої находження при збереженні платоспроможності і кредитоспроможності, та забезпечення фрінансової рівноваги для забезпечення достатнього обсягу фрінансових ресурсів.
\end{abstract}

Ключові слова: фрінансові результати, чистий дохід, нерозподілений прибуток, прибуток, ефективність діяльності.

Статья посвящена исследованию теоретических основ формирования прибыли предприятия и определение основных методов управления им. Определены основные фракторы влияния на формирование прибыли предприятия. Исследованы особенности формирования прибыли и ее распределение для успешного ведения фринансово-хозяйственной деятельности субъекта хозяйствования. Поскольку основной целью распределения прибыли предприятия, остающейся в его распоряжении, является оптимизация пропорции между частью чистой прибыли, потребляемой и частью, которая остается в кругообороте средств предприятия. Процесс фрормирования прибыли является целой совокупностью форм и методов, которые позволяют предприятию оптимизировать и увеличить свои нахождение при сохранении платежеспособности и кредитоспособности, и обеспечения фринансового равновесия для обеспечения достаточного объема фринансовых ресурсов.

Ключевые слова: фринансовые результаты, чистый доход, нераспределенная прибыль, прибыль, эфффективность деятельности.

In today's market conditions, making a profit is the main purpose of financial and economic activities, and opportunities for its optimization indicate the effectiveness of any enterprise or organization. The pre-tax financial result from the main activity is the main indicator from which the profit of the enterprise is formed after payment of taxes. However, as a rule, the company's costs exceed revenues, which leads to losses. The company's profit is the main factor of its economic and social development. It is a source of self-financing, incentives, the supplier must examine the financial statements of the counterparty, and therefore pays attention to profits, as it is a source of equity of the enterprise and speaks of the ability to pay for the delivered products. Features of the formation and management of profits is a very important aspect for the proper functioning of the enterprise, which must be developed with new approaches and methods of managing it. The article is devoted to the study of the theoretical foundations of the formation of enterprise profits and the definition of basic methods of managing it. The main factors influencing the formation of enterprise profits and their management are identified. When making decisions on the distribution of 
net profit, the company must find the optimal ratio in the direction of additional financial resources for production and technical development, social development, material incentives for workers (shareholders, shareholders) and for other purposes. Also, the peculiarities of the formation of the company's profit and its distribution for the successful conduct of financial and economic activities of the business entity in order to obtain the economic effect of the main activity. Since the main purpose of the distribution of profits of the enterprise, which remains at its disposal, is to optimize the ratio between the part of net profit consumed and the part that remains in the circulation of funds of the enterprise. And the process of profit formation is a set of forms and methods that allow the company to optimize and increase its findings while maintaining solvency, creditworthiness, asset turnover and financial balance to ensure sufficient financial resources and economic effect.

Keywords: financial results, net profit, retained earnings, profit, efficiency of activity.

Постановка проблеми. В умовах ринкової економіки прибуток є найважливішим критерієм успішної роботи підприємств, який характеризує остаточний результат усіх видів діяльності і джерелом приросту активів їх власників. В той же час, з кожним роком стан фрормування фрінансових результатів вітчизняних підприємств погіршується. В сучасних умовах перед будь-яким підприємством постає завдання отримати максимальний прибуток від своєї діяльності, проте, такий ефрект можливий лише у результаті правильного розподілу, срормування та управління результатом своєї діяльності.

Аналіз останніх досліджень та публікацій. Питаннями формування фрінансових результатів, займались такі вчені-економісти як А. Басенко, Т. Білик, І. Бланк, Л. Дікань, А. Касич, С. Николишин, Г. Савицька, А. Турило та інші. В той же час, невизначеність багатьох теоретичних положень, недосконалість нормативного й методичного забезпечення процесу обліку і аналізу фрінансових результатів діяльності підприємств та недостатній рівень дослідження проблеми зумовили завдання та логіко-структурну побудову дослідження.

Виділення невирішених раніше частин загальної проблеми. В сучасних умовах господарювання прибуток $\epsilon$ основною метою фрінансово-господарської діяльності підприємств та організацій. Тому наразі на підприємствах виникають проблеми зі здійсненням управлінням прибутком з метою його оптимізації.

Формулювання цілей статті. Метою дослідження $€$ обґрунтування теоретичних та організаційно-методичних положень, а також розробка практичних рекомендацій з удосконалення фрормування та розподілу фрінансових результатів підприємств.

Виклад основного матеріалу. Дослідженням питанням сутності поняття «прибуток» займалося безліч вчених-економістів. Наприклад, Бланк І., трактує «прибуток» як втілений у грошовій фрормі чистий дохід підприємця на вкладений капітал, що характеризує його винагороду за ризик здійснення підприємницької діяльності та $€$ різницею між сукупним доходом і сукупними витратами в процесі здійснення цієї діяльності. Данилов О. та Паєнтко Т. визначають прибуток як складову власного капіталу. Поддєрьогін А. вказує на те, що прибуток - це частина реалізованої вартості, створеної і реалізованої, готової до розподілу.

Прибуток, займаючи центральне місце в ринковій економіці, є стимулом для суб'єктів господарювання якомога ефективніше використовувати наявні трудові, матеріальні та фрінансові ресурси. Позитивний фрінансовий результат - прибуток - $€$ метою, заради якої працює або, принаймні, повинно працювати підприємство.

Прибуток підприємства - основний чинник його економічного і соціального розвитку. Це підтверджується тим, що прибуток $€$ джерелом самофрінансування, стимулювання соціально-економічного розвитку виробництва і матеріального заохочення персоналу. Прибуток виступає в якості оціночного показника, $€$ основним джерелом власного капіталу підприємств, а саме джерелом розширення виробництва і забезпечення інших потреб підприємства. Діючий порядок розподілу прибутку відповідає нинішньому етапу становлення ринкових відносин, тобто підприємство повинне брати участь своїм прибутком у фрормуванні державного бюджету, а частина прибутку, що залишилася, повинна бути розподілена між власником підприємства і власником позичкового капіталу і інших фрінансових ресурсів відповідно до укладених договорів.

Успішне фрункціонування підприємства на ринку того чи іншого товару визначається його здатністю приносити достатній дохід для відшкодування витрат і фрормування прибутку. Отже, прибуток, будучи фрінансовим результатом підприємства, характеризує абсолютну ефрективність його діяльності [1, с. 229]. Особливості фрормування прибутку підприємств у своїй 
праці визначає Старинець О., а саме: «фрормування й розподіл прибутку полягає у тому, що їх існує дуже багато чинників впливу. Врахувати й оцінити всю кількість чинників неможливо,тому необхідна деяка їх систематизація» [7, с. 172]. Овчарик В., зазначає, що «на фрормування прибутку впливають постановка мети підприємства, виробничі і фрінансові чинники, а також облікова політика в області ведення бухгалтерського обліку і оподаткування. Разом з тим, показники фрінансових результатів діяльності підприємства відображають компетентність керівництва і якість управлінських рішень». Жадько К.С.: «основними елементами у структурі механізму управління прибутком є: державне правове і нормативне регулювання питань формування та розподілу прибутку підприємства; ринковий механізм регулювання формування і використання прибутку підприємства; внутрішній механізм регулювання окремих аспектів формування, розподілу і використання прибутку підприємства; система конкретних методів і прийомів здійснення управління прибутком» [2, с. 58].

Тільки після продажу, продукції чистий дохід приймає форму прибутку. 3 одержаного прибутку підприємства сплачують до бюджету податок на прибуток та поновлюють власний капітал, створюють резервний капітал, виплачують дохід учасникам та здійснюють інші заходи, передбачені законодавством і установчими документами. Напрями розподілу нерозподіленого прибутку визначаються власниками підприємства або їхніми уповноваженими органами згідно 3 установчими документами [6, с. 457].

При прийнятті рішень про розподіл чистого прибутку підприємство повинно знайти оптимальне співвідношення у спрямуванні додаткових фрінансових ресурсів на цілі виробничотехнічного розвитку, соціального розвитку, матеріального заохочення трудівників (акціонерів, пайовиків) і на інші цілі. Фонд коштів на розвиток і вдосконалення виробництва (фонд накопичення) витрачається на задоволення потреб, які пов'язані зі зростанням обсягів виробництва, технічним переозброєнням, вдосконаленням технології виробництва та інших потреб, що забезпечують зростання і вдосконалення матеріально-технічної бази підприємство.

Обсяг реалізації і величина прибутку, рівень рентабельності залежать від виробничої, постачальницької, маркетингової і фрінансової діяльності підприємства, інакше кажучи, ці показники характеризують всі сторони господарювання [4, с. 9].
Для узагальнення інформації про формування і використання фрінансових результатів господарської діяльності підприємства використовується рахунок 44 «Нерозподілені прибутки (непокриті збитки)».

Фінансовий результат визначають на рахунку 79 «Фінансові результати». Після чого прибуток списують в кредит рахунку 441 «Прибуток нерозподілений», а збиток в дебет рахунку 442 «Непокриті збитки».

Визнання та вимірювання доходу і витрат, а значить і прибутку, частково залежить від концепцій капіталу та збереження капіталу, які суб'єкт господарювання використовує при складанні своїх фрінансових звітів: фр. № 1 «Баланс (Звіт про фрінансовий стан)» та фр. № 2 «Звіт про фрінансові результати (Звіт про сукупний дохід)» [5].

При аналізі фрінансових результатів дослідження проводять у двох аспектах. У першому аспекті фрінансовий результат оцінюють як ступінь досягнення кінцевої мети та визначення ефрективності виробничо-срінансової діяльності.

Другий аспект передбачає визначення пріоритетів вкладення капіталу за видами діяльності, за масштабами у стратегічному та тактичному вимірах, які дають максимальний приріст фрінансового результату. Безумовно, бажаним результатом будь-якої підприємницької діяльності є прибуток, який при відповідних його обсягах, дає можливість для саморозвитку та збільшення масштабів діяльності суб'єкта господарювання.

Отже, на формування абсолютної суми прибутку підприємства впливають результати, тобто ефективність його фрінансовогосподарської діяльності, сфрера діяльності, галузь господарства.

Для ефективного функціонування суб'єктів господарювання в умовах ринкових відносин найбільше значення має виявлення резервів збільшення об'єму продукції, зниження собівартості, росту прибутку. Резерви зростання прибутку - це кількісно вимірні можливості його збільшення за рахунок зростання об'єму реалізації продукції, зменшення витрат на її виробництво і реалізацію, недопущення зовні реалізаційних збитків, вдосконалення структури виробленої продукції.

Одним із резервів росту прибутку підприємства $€$ збільшення обсягу реалізації продукції. Між прибутком та обсягом реалізації існує пряма залежність, тобто чим більше продукції реалізується, при інших рівних умовах, тим більшою є сума прибутку, і навпаки, невиконання плану по реалізації зменшує прибуток. 
Одним із резервів росту прибутку підприємства є збільшення обсягу реалізації продукції. Між прибутком та обсягом реалізації існує пряма залежність, тобто чим більше продукції реалізується, при інших рівних умовах, тим більшою $є$ сума прибутку, і навпаки, невиконання плану по реалізації зменшує прибуток.

Слід звернути увагу, що отримання прибутку суб'єктами господарювання пов'язане 3 діяльністю не тільки на території України, а й за її межами. Засоби або майно, отримані підприємством безкоштовно, до складу прибутку не включаються.

Проте, дуже часто підприємство маючи прибуток може нерозумно ним розпоряджатися, і мати фрінансові труднощі. Розподіл прибутку пропорційно до участі в його фрормуванні буде основним стимулом, як для участі у виробничому процесі, так і в поліпшенні економічних результатів для всіх учасників виробничого процесу. Це дасть можливість зацікавити кожного працівника у виробничому процесі, в отриманні підприємством максимального прибутку [3, с. 19-20].

А тому на підприємствах необхідно реалізувати ефективні заходи, зокрема: провести детальний аналіз підприємства і розробити організаційно-економічні рекомендації для створення системи управлінського обліку, удосконалити систему управлінського обліку щодо фрормування та раціонального використання прибутку підприємства.

Для цього слід у положення про відділи, в посадові інструкції кожного керівника персоналу внести доповнення у вигляді визначення відповідальності за нераціональне, неефективне використання ресурсів у відо- мчому йому підрозділі, провести заходи щодо своєчасності надходження грошових коштів 3 виконаних робіт шляхом інвентаризації дебіторської заборгованості, виявлення причин іiї утворення і термінів погашення, контроль за дотриманням умов договорів, у зв'язку зі збільшенням собівартості продукції виявити внутрішні резерви щодо її зниження [8, с. 127].

Таким чином, на фрінансові результати діяльності підприємств, впливають різні фрактори виробничої та фрінансової діяльності, які виявляють себе з перебігом часу. Це призводить до того, що підприємство нераціонально використовує прибуток, отриманий від основної діяльності. I задля запобігання витрачання коштів підприємства необхідно посилити внутрішній контроль та вжити організаційно-економічних засобів ведення управлінського обліку.

Висновки. Значення прибутку на підприємстві $€$ вагомим, оскільки він $€$ основним джерелом фрінансування. Тому особливостями формування, управління та розподілу прибутку є діяльність осіб, які відповідальні за ведення фрінансово-господарської діяльності, яка повинна бути спрямована на оптимізацію та зростання підсумкових показників. Прибуток $€$ основним чинником самофрінансування та економічного розвитку підприємства. Авторами визначено, що основними методами управління прибутком $€$ державне, правове управління. а також система розроблених заходів на підприємстві. А тому основними рекомендаціями для ефективного управління прибутком підприємства є розроблення заходів щодо аналізу діяльності всіх показників, що впливають на формування прибутку та пошук методів його оптимізації.

\section{СПИСОК ВИКОРИСТАНИХ ДЖЕРЕЛ:}

1.Дембовський Е.Д. Управлінський облік та аналіз фрормування прибутку підприємства : Збірник наукових праць VII Всеукраїнської студентської науково-практичної консреренції «Актуальні проблеми ефрективного соціально-економічного розвитку України: пошук молодих». 2018. № 55. С. 227-235.

2.Жадько К.С. Управління прибутком суб'єкта підприємницької діяльності : Матеріали міжнародної науково-практичної конореренції «економіко-правові та управлінські аспекти розвитку суспільства: молодіжний погляд». 2019. С. 58-60.

3.Линник О.І., Шейн А.М. Облік формування прибутку на підприємстві. 2017. С. 19-20.

4.Мурашко О.В. Формування і розподіл прибутку підприємства. Науковий вісник УМО «Економіка та управління». 2016. № 1. С. 1-12.

5.Про затвердження Національного положення (стандарту) бухгалтерського обліку 1 «Загальні вимоги до фрінансової звітності» : наказ Міністерства фрінансів України від 07.02.2013 № 73. URL: https://zakon.rada.gov.ua/ laws/show/z0336-13\#Text

6.Свирида О.В., Марковська Н.В. Особливості обліку фрормування та використання прибутку підприємств. Економіка та управління: сучасний стан та перспективи розвитку. 2018. С. 455-458.

7.Старинець О.Г. Особливості формування та розподілу прибутку підприємств зв'язку. Науковий вісник Херсонського державного університету. 2018. Том 1. № 28. С. 170-173. 
8. Хоменко Д., Овчарик 3. Особливості фрормування і використання прибутку підприємства : Міжнародна науково-практична конференція «Сучасна соціально-економічна система: парадигма, завдання і тенденції». 2018. С. $127-128$.

\section{REFERENCES:}

1. Dembovsky E.D. (2018) Management accounting and analysis of the formation of enterprise profits: Collection of scientific works of the VII All-Ukrainian student scientific-practical conference «Actual problems of effective socio-economic development of Ukraine: search for young people», vol. 55, pp. 227-235.

2. Zhadko K.S. (2019) Business profit management: Proceedings of the international scientific-practical conference «economic, legal and managerial aspects of society: youth view».

3. Linnik O.I., Shane A.M. (2017) Accounting for the formation of profits in the enterprise.

4. Murashko O.V. (2016) Formation and distribution of enterprise profits. Scientific Bulletin of UMO «Economics and Management», vol. 1, pp. 1-12.

5. On approval of the National Regulation (standard) of accounting 1 «General requirements for financial reporting»: Order of the Ministry of Finance of Ukraine dated 07.02.2013 № 73. Available at: https://zakon.rada.gov.ua/laws/ show/z0336-13\#Text (accessed 29 March 2020).

6. Svirida O.V., Markovskaya N.V. (2018) Features of accounting for the formation and use of corporate profits. Economics and management: current status and development prospects.

7. Starinets O.G. (2018) Features of formation and distribution of profit of communication enterprises. Scientific Bulletin of Kherson State University, vol. 1(28), pp. 170-173.

8. Khomenko D., Ovcharik Z. (2018) Features of the formation and use of enterprise profits. International scientific-practical conference «Modern socio-economic system: paradigm, tasks and trends». 